\title{
The rule of competence, compensation, and workshop on employee performance mediated by prime service of public health service
}

\author{
Ivalaina Astarina $^{a^{*}}$, Budiyanto ${ }^{\mathrm{a}}$ and Agustedi ${ }^{\mathrm{a}}$
}

${ }^{a}$ Sekolah Tinggi Ilmu Ekonomi Indonesia (STIESIA) Surabaya, Indonesia

\begin{tabular}{l} 
C H R O N I C L E \\
\hline Article history: \\
Received: July 2, 2020 \\
Received in revised format: \\
September 302020 \\
Accepted: October 8, 2020 \\
Available online: \\
October 12, 2020 \\
\hline Keywords: \\
Competence \\
Compensation \\
Workshop \\
Kompensasi \\
Diklat \\
Prime Service \\
Employee Performance
\end{tabular}

\section{Introduction}

Competence simultaneously affects employee performance according to the research done by previous research focusing on employee parameters (Ramo et al., 2009; Chan, 2006; Sengupta et al., 2013; Zainol \& Mamun., 2018; Emmerling et al., 2012; Yang et al., 2012). On the other hand, there are different results which conclude that competence has no effect or influence on employee performance whatsoever (Ahrul Tsani., 2013; Ratnasari., 2016). These studies concluded that competence has no effect on performance. Research related to employee compensation (Chong \& Law., 2016; Jean et al., 2017; Do, 2018; Feng et al., 2015; Leung and Chan., 2001) concluded that compensation has an effect on performance. However, there are different research as a counter-results from the empirical research (Antonia et al., 2019; Rizal et al., 2014; Hamed et al., 2014) which states that compensation has no effect or influence vice versa on work performance. Education and workshop have an effect on employee performance preserved by former research (Ningrum et al., 2013; Elnaga \& Imran, 2013; Athar \& Shah, 2015; Fitrio et al., 2020). On the other hand, there are different results which conclude that education and workshop does not have a significant effect on employee performance. The research was done by Pakpahan et al. (2014). Thus, the researchers conclude that there is no consistency in the results of research from previous researchers. This is a research gap regarding competency, compensation and workshop variables on employee performance so that further research is necessary. The choice of variables

* Corresponding author.

E-mail address: ivalainaastarina@stieindragiri.ac.id (I. Astarina)

(C) 2021 by the authors; licensee Growing Science, Canada doi: $10.5267 / \mathrm{j}$.ac.2020.10.013 
in this study is based on previous research studies which still show a research gap. To provide a wider result as a solution to this gap research, the researcher uses a mediation approach. This is based on empirical and theoretical studies and is supported by phenomena in the field. Researchers suspect that there are other variables that are different and can fill this research gap, namely the prime service variable. Through excellent service as mediation it can increase the effect of competence, compensation and workshop on employee performance at the Public Health Service or Pusat Kesehatan Masyarakat (Puskesmas). Researchers have not found any previous research that discusses excellent service as a mediating variable or uses prime service variable as mediation in the related field.

\section{Literature Review and Hypotheses Development}

\section{The Effect of Competence on Employee Performance}

Decree of the Head of the State Civil Service Agency No 46A of 2003 states that competence is the ability and characteristics possessed by a civil servant in the form of knowledge, skills, and behavioral attitudes and these domain are needed in carrying out their duties, so that the civil servants can carry out their duties professionally, effectively, and efficiently. Competency indicators according to Spencer and Spencer (1993) are: (1) Beliefs and values, (2) Skills, (3) Experience, (4) Personality characteristics, and (5) Intellectual abilities. These competency indicators will be used as parameters of variable.

\section{$\mathrm{H}_{1}$ : Competence has a significant effect on Employee Performance at Puskesmas in Indragiri Hulu Regency.}

\section{The Effect of Compensation on Employee Performance}

Nurjaman (2014: 179) states that compensation is something that employees receive in return for their performance in carrying out their duties based on the work load and wage. Compensation is the overall arrangement for the provision of remuneration for employees and managers, both in the form of financial to goods and services received by each employee (Sihotang, 2007: 220). Rivai (2010: 741) provides an understanding of compensation, which is something that employees receive as a substitute for their service contribution to the company. Compensation is all income in the form of money; direct or indirect goods received by employees in return for services provided to the company (Hasibuan, 2014: 118). Compensation refers to all forms of financial returns and tangible services and benefits received by employees as part of a working relationship (Bhattacharya and Sengupta, 2009: 02). Bangun (2012) states that compensation can be measured by indicators: (1) Salary, (2) Incentives, (3) Bonuses, (4) Wages, (5) Premiums, (6) Medications, and (7) Insurance.

$\mathrm{H}_{2}$ : Compensation has a significant effect on Employee Performance at Puskesmas in Indragiri Hulu Regency.

\section{The Effect of Workshop on Employee Performance}

The definition of education training and workshop, according to Ambar (2009: 219), is an effort to maintain process to increase the ability, capacity, and professionalism of employees. This is important because of the methods used by the organization to maintain, arrange, and manage public employees in the organization and at the same time improve the skills of employees so that they can improve their performance. Rae (2005) suggests that the indicators of education training / workshop are: (1) Workshop content, (2) Workshop methods, (3) Attitudes and skills of instructors, (4) Duration of workshop, and (5) Workshop facilities.

H3: Workshop has a significant effect on Employee Performance at Puskesmas in Indragiri Hulu Regency.

\section{The Effect of Competence on Employee Performance Mediated by Prime Service}

According to Payaman (2009: 14), an individual performance model is influenced by human and non-human factors including individual competence (in the form of abilities and skills), work discipline, motivation, attitudes and work ethic, management support (in the form of industrial relations and leadership), and organizational support (in the form of work culture, organizational structure, technology and equipment, and working conditions). Mangkuprawira and Hubeis (2007: 153) state that performance is the result of a certain planned work process at the time and place of the employee and the organization concerned. Murpy and Cleveland (in Pasolong 2007: 17) state that performance is the quality of task-oriented behavior and work. This means that employee performance in an organization is determined by the attitude and behavior of employees towards their work and the orientation in carrying out the work.

$\mathrm{H}_{4}$ : Competence has a significant effect on Employee Performance mediated by Prime Service at Puskesmas in Indragiri Hulu Regency.

\section{The Effect of Compensation on Employee Performance Mediated by Prime Service}

Compensation refers to all forms of financial returns and tangible services and benefits received by employees as part of a working relationship (Bhattacharya and Sengupta, 2009: 02). Compensation as a style of social control has been found in many 
if not all cultures of working environment. Usually this style of compensation is initiated by someone to fulfill an obligation due to the contract. Compensation will be considered in the context of several broader modes of social control (Black, 2014: 191). If the compensation provided, both in civil servants and non-civil servants work load, it is in accordance with the provisions. So, it is assumed that the employers are able to provide prime service so that the employees' performance will increase in line with their satisfaction in working.

\section{$\mathrm{H}_{5}$ : Compensation has a significant effect on Employee Performance mediated by Prime Service at Puskesmas in Indragiri Hulu Regency.}

\section{The Effect of Workshop on Employee Performance Mediated by Prime Service}

Mangkuprawira and Hubeis (2007: 160) state that employee performance is influenced by employee intrinsic and extrinsic factors. Intrinsic factors that affect employee performance consist of education, experience, motivation, health, age, skills, emotion, and spirituality. Meanwhile, extrinsic factors that affect employee performance consist of physical and non-physical environment, leadership, vertical and horizontal communication, compensation, control in the form of supervision, facilities, workshop, workload, work procedures, punishment system, and so on. According to Sedarmayanti (in Gatot Subrata, 2009: 38), there are several factors that influence performance achievement or work performance, namely the ability and the motivation factor. The ability factor is obtained from knowledge and skills while motivation is formed from the attitude in dealing with work situations.

$\mathrm{H}_{6}$ : Workshop has a significant effect on Employee Performance mediated by Prime Service at Puskesmas in Indragiri Hulu Regency.

\section{Previous Research}

Previous research on the effect of Competence, Compensation, and Workshop on the Employee Performance in this study can be seen in Table 1 of this article.

\section{Table 1}

Previous Research on the Effect of Competence, Compensation, and Workshop on Employee Performance

\begin{tabular}{|c|c|c|c|c|c|c|c|c|c|}
\hline No & Researcher & Year & Variable & Result & No & Researcher & Year & Variable & Result \\
\hline 1 & Ramo et al. & 2009 & Comp - Perf & Significant & 33 & Komara, et al. & 2014 & Compenst - Perf & Significant \\
\hline 2 & Chan & 2006 & Comp - Perf & Significant & 34 & Wardhana & 2018 & Compenst - Perf & Significant \\
\hline 3 & Sengupta et al. & 2013 & Comp - Perf & Significant & 35 & Rizal, et al. & 2014 & Compenst - Perf & Insignificant \\
\hline 4 & Zainol \& Mamun & 2018 & Comp - Perf & Significant & 36 & Hameed, et al. & 2014 & Compenst - Perf & Insignificant \\
\hline 5 & Emmerling et al. & 2012 & Comp - Perf & Significant & 37 & Anthonia, et al. & 2019 & Compenst - Perf & Insignificant \\
\hline 6 & Yang, et al. & 2012 & Comp - Perf & Significant & 38 & Athar \&Shah & 2015 & Work - Perf & Significant \\
\hline 7 & Shah \& Prakash & 2018 & Comp - Perf & Significant & 39 & Elnaga \& Imran & 2013 & Work - Perf & Significant \\
\hline 8 & Tognazzo, et al. & 2017 & Comp - Perf & Significant & 40 & Anitha \& Kumar & 2016 & Work - Perf & Significant \\
\hline 9 & Otoo & 2019 & Comp - Perf & Significant & 41 & Farooq \& Khan & 2011 & Work - Perf & Significant \\
\hline 10 & Ren, et al. & 2015 & Comp - Perf & Significant & 42 & Younas, et al. & 2018 & Work - Perf & Significant \\
\hline 11 & Ataunur \& Ariyanto & 2015 & Comp - Perf & Significant & 43 & Kum, et al. & 2014 & Work - Perf & Significant \\
\hline 12 & Muqiit & 2014 & Comp - Perf & Significant & 44 & Khan, et al. & 2014 & Work - Perf & Significant \\
\hline 13 & Yuliana & 2017 & Comp - Perf & Significant & 45 & Shaheen, et al. & 2013 & Work - Perf & Significant \\
\hline 14 & Rahman & 2015 & Comp - Perf & Significant & 46 & Imran \& Tanveer & 2015 & Work - Perf & Significant \\
\hline 15 & Indriani & 2018 & Comp - Perf & Significant & 47 & Barzegar \& Farjad & 2011 & Work - Perf & Significant \\
\hline 16 & Tsani & 2013 & Comp - Perf & Insignificant & 48 & Dermol \& Cater & 2013 & Work - Perf & Significant \\
\hline 17 & Ratnasari & 2016 & Comp - Perf & Insignificant & 49 & Hansson & 2007 & Work - Perf & Significant \\
\hline 18 & Adam \& Kamase & 2019 & Comp - Perf & Insignificant & 50 & Ibrahim & 2017 & Work - Perf & Significant \\
\hline 19 & Marin \& Sanchez & 2002 & Compenst - Perf & Significant & 51 & Hasanah & 2010 & Work - Perf & Significant \\
\hline 20 & Appelbaum \& Mackenzie & 1996 & Compenst - Perf & Significant & 52 & Ningrum, et al. & 2013 & Work - Perf & Significant \\
\hline 21 & Bento \& White & 2006 & Compenst - Perf & Significant & 53 & Andri & 2011 & Work - Perf & Significant \\
\hline 22 & Chong \& Law & 2016 & Compenst - Perf & Significant & 54 & Aulia \& Sasmita & 2014 & Work - Perf & Significant \\
\hline 23 & Do & 2018 & Compenst - Perf & Significant & 55 & Yuliana & 2017 & Work - Perf & Significant \\
\hline 24 & Feng, et al. & 2015 & Compenst - Perf & Significant & 56 & Pakpahan, et al. & 2014 & Work - Perf & Insignificant \\
\hline 25 & Leung \& Chan & 2001 & Compenst - Perf & Significant & 57 & Singh & 2016 & Ply - Perf & Significant \\
\hline 26 & Vlachos & 2009 & Compenst - Perf & Significant & 58 & Lima, et al. & 2010 & Ply - Perf & Significant \\
\hline 27 & Yang & 2016 & Compenst - Perf & Significant & 59 & Liang, et al. & 2010 & Ply - Perf & Significant \\
\hline 28 & Baledi \& Saed & 2017 & Compenst - Perf & Significant & 60 & Fahrurrozi & 2013 & Ply - Perf & Significant \\
\hline 29 & Jean, et al. & 2017 & Compenst - Perf & Significant & 61 & Hakim & 2014 & Ply - Perf & Significant \\
\hline 30 & Sukidi \& Wajdi & 2016 & Compenst - Perf & Significant & 62 & Santhi \& Hartati & 2017 & Ply - Perf & Significant \\
\hline 31 & Mulyadi & 2012 & Compenst - Perf & Significant & 63 & Nuraini & 2016 & Ply - Perf & Insignificant \\
\hline 32 & Ramadhan, et al. & 2015 & Compenst - Perf & Significant & & & & & \\
\hline
\end{tabular}

Source: Data was retrieved and summarized by the researchers from literature studies

\subsection{Formulating the Research Problems}

Based on the introduction and the research gap analyzed in the previous section, the formulation of the research problems in this study was done as follows.

a. Does Competency have a significant effect on Employee Performance at Puskesmas in Indragiri Hulu Regency?

b. Does Compensation have a significant effect on Employee Performance at Puskesmas in Indragiri Hulu Regency? 
c. Does Workshop have a significant effect on Employee Performance at the Puskesmas in Indragiri Hulu Regency?

d. Does Competence have a significant effect on Employee Performance mediated by Prime Service at Puskesmas in Indragiri Hulu Regency?

e. Does Compensation have a significant effect on Employee Performance mediated by Prime Service at Puskesmas in Indragiri Hulu Regency?

f. Does Workshop have a significant effect on Employee Performance mediated by Prime Service at Puskesmas in Indragiri Hulu Regency?

\subsection{Conceptual Framework}

The conceptual framework is needed to bridging the research variables done in the process. The conceptual framework of this research can be seen in Fig. 1.

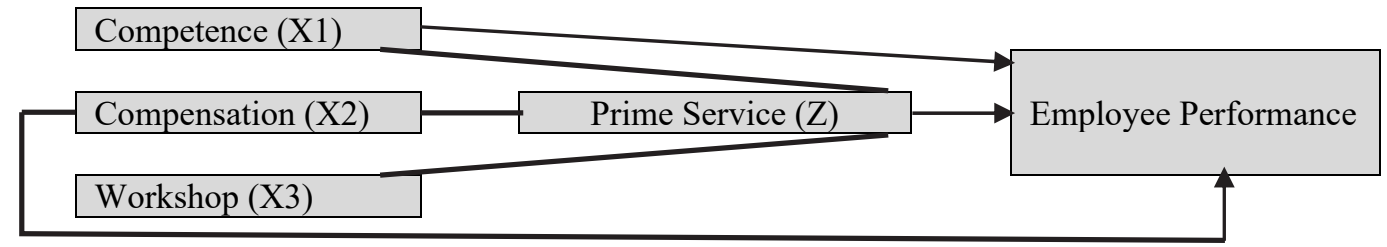

Fig. 1. Conceptual Framework

\section{Research Methodology}

This research uses a positivistic approach using descriptive quantitative methods. Creswell (2008: 5) says that quantitative research is a method for testing certain theories by examining the relationship between variables. The population of this study was 127 people; all employees of the Puskesmas in Indragiri Hulu Regency. The sample was taken using a lottery technique. The questionnaires were tested for validity and reliability using the IBM SPSS 24 application. The hypotheses were tested using the SMARTPLS 3.0 application. Employee performance is measured by indicators of Government Decree Number 33 of 2019 namely: (1) Service Orientation, (2) Integrity, (3) Commitment, (4) Discipline, (5) Cooperation, and (6) Leadership. Competence is measured by indicators developed from Spencer and Spencer (1993) namely: (1) Beliefs and values, (3) Skills, (3) Experience, (4) Personal characteristics, and (5) Intellectual ability. Compensation is measured by indicators developed by Bangun (2012) namely: (1) Salary, (2) Incentives, and (3) Insurance. Workshop is measured by indicators developed from Rae (2005) namely: (1) Workshop content, (2) Methods, (3) Attitudes and skills of instructors, (4) Length of time, and (5) Facilities. Prime service according to the health department is measured by indicators namely: (1) User satisfaction, (2) Service process, (3) Human resources and customer satisfaction, (4) Process and human resources, (5) Human resources and service processes, and (6) Customer satisfaction and human resources.

\section{Empirical Results and Discussions}

\subsection{Instrument Testing}

If the correlation coefficient ( $\mathrm{r}$ count) $\geq 0.3$, it can be concluded that the statement item is valid. Meanwhile, if the correlation coefficient ( $\mathrm{r}$ count) $\leq 0.3$, it can be concluded that the statement item is invalid (Sugiyono, 2016: 183). From the test results, all statement items have a correlation coefficient $\geq 0.3$, it can be concluded that all statement items are valid. The variable is declared reliable if the alpha Cronbach coefficient value $>0.60$, it means that the reliability level of 0.60 is an indication of the reliability of a construct (Sugiyono 2016: 184). From the test results, all Cronbach alpha values $>0.6$, it means that each item of the questionnaire statement from each variable is able to form the construct of this variable. Thus, the list of statements throughout the questionnaire is reliable for measuring each variable.

\subsection{Analysis of Measurement Model (Outer Model)}

Validity Test

The analysis of measurement model or outer model was done in determining the validity test due to the correlation between variables. It can be seen in Fig. 2. 


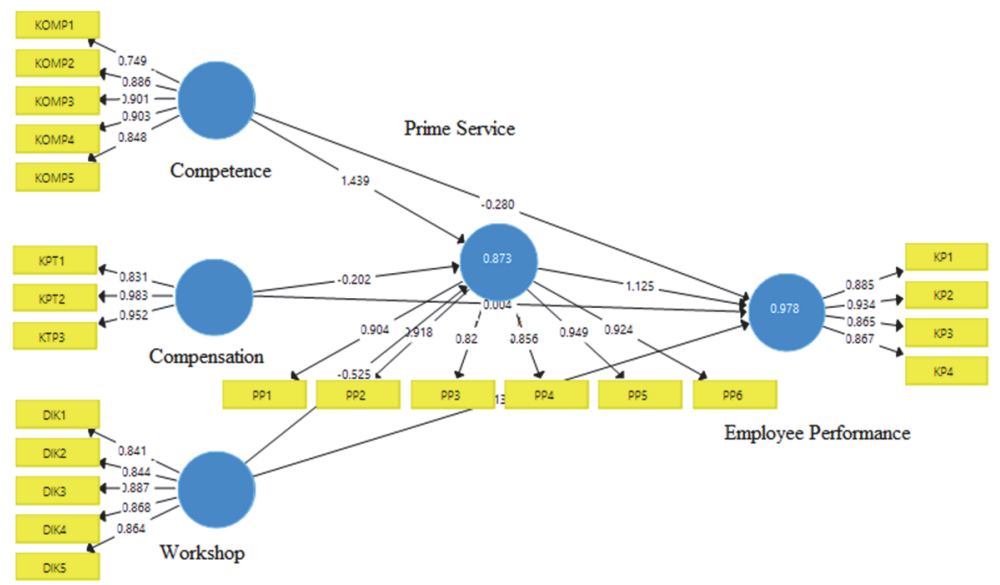

Fig. 2. Validity Testing

A loading value of 0.7 or more is considered very satisfying (Henseler et al., 2009; Gotz et.al., 2010) while indicators that have a loading factor value equal to 0.5 are considered acceptable and indicators with a loading factor value of less than 0.5 must be removed (Chin, 1998; Hair et al., 2010). From Fig. 2 it can be seen that all factor loading values are greater than 0.7. It means that all indicators in the research variable are valid.

\section{Reliability Test}

The analysis of reliability was done in determining the reliability of the questionnaires due to the correlation between variables. It can be seen in Table 2.

\section{Table 2}

Reliability Test

\begin{tabular}{lcc}
\hline & Variable & Cronbach's Alpha \\
\hline Competence (X1) & 0.952 & 0.978 \\
Compensation (X2) & 0.963 \\
Workshop (X3) & 0.985 & 0.940 \\
Prime Service (Z) & 0.954 & 0.958 \\
\hline
\end{tabular}

Source: Data was analyzed by the researchers using SmartPLS application results.

The reliability test in PLS can use two methods namely Cronbach's Alpha and composite reliability. Cronbach's Alpha measures the lower limit of the reliability value, while composite reliability measures the real value of the reliability of a construct (Chin \& Gopal, 1995). Composite reliability is considered to be better in estimating the internal consistency of a construct (Werst et al., 1974). The rule of thumb for Cronbach's Alpha value and composite reliability must be greater than 0.70 although the value of 0.60 is still acceptable (Hair et al., 2006). From Table 2 we can see that Cronbach's Alpha and composite reliability is greater than 0.70 , which means that the construct of the research model consists of competence, compensation, workshop, and prime service reliably.

\subsection{Analysis of Structural Model (Inner Model)}

\section{Analysis of Determinacy Coefficient (R-Square)}

The analysis of structural model or inner model was done in determining the analysis of determinacy coefficient or R-Square of the variables. It can be seen in Table 3 .

\section{Table 3}

\section{R-Square Scores}

\begin{tabular}{lcc}
\hline & Variable & R Square \\
\hline Competence (X1) & - \\
Compensation (X2) & 0.815 & 0.746 \\
Workshop (X3) & 0.871 \\
Prime Service (Z) & 0.874 \\
Employee Performance (Y) & \\
\hline
\end{tabular}

Source: Data was analyzed by the researchers using SmartPLS application results. 
$\mathrm{R}^{2}$ results of $0.67,0.33$, and 0.19 for endogenous variables in the structural model indicate that the model is "good", "moderate", and "weak" (Ghozali, 2014). The goodness of fit in the PLS model can be seen from the $\mathrm{R}^{2}$ value; the higher the $\mathrm{R}^{2}$, the more fit the model can be. The results of the calculation of $\mathrm{R}^{2}$ of the employee performance variable show a value of 0.874 and it was more than 0.67. It means that the model is fit so that the magnitude of the diversity of the research data can be explained by the structural model and has a good relevant value because the value is almost close to one. The results can lead to the hypotheses testing.

\subsection{Hypotheses Testing Results}

The analysis of inner and outer model was done so that the hypotheses testing can be performed. Table 4 shows the results of hypotheses testing in this study.

\section{Table 4}

Hypotheses Testing

\begin{tabular}{|c|c|c|c|c|}
\hline Correlation Between Variables & $\begin{array}{c}\text { Original } \\
\text { Sample }(\mathrm{O})\end{array}$ & $\begin{array}{l}\text { T Statistics } \\
(\mathrm{O} / \mathrm{STDEV})\end{array}$ & $\begin{array}{c}\mathrm{P} \\
\text { Values }\end{array}$ & Result \\
\hline Competence $\rightarrow$ Employee Performance & 0.291 & 3.813 & 0.000 & Has an Effect \\
\hline Compensation $\rightarrow$ Employee Performance & 0.253 & 2.531 & 0.012 & Has an Effect \\
\hline Workshop $\rightarrow$ Employee Performance & 0.218 & 3.144 & 0.002 & Has an Effect \\
\hline Competence $\rightarrow$ Prime Service $\rightarrow$ Employee Performance & 0.090 & 2.545 & 0.011 & Has an Effect \\
\hline Compensation $\rightarrow$ Employee Performance $\rightarrow$ Prime Service $\rightarrow$ Employee Performance & 0.103 & 2.437 & 0.015 & Has an Effect \\
\hline Workshop $\rightarrow$ Prime Service $\rightarrow$ Employee Performance & 0.078 & 2.541 & 0.011 & Has an Effect \\
\hline
\end{tabular}

Source: Data was analyzed by the researchers using SmartPLS application results.

Abdillah and Jogiyanto (2015: 197) state that the coefficient path or inner model score indicated by the T statistic value must be above 1.96 for hypothesis testing at 5 percent alpha.

\section{$\mathrm{H}_{1}$ : Competence has a significant effect on Employee Performance at Puskesmas in Indragiri Hulu Regency.}

The effect of the competency variable on employee performance variable is 0.291 with a t-statistics value of 3.813 , where the $\mathrm{t}$-statistics value is greater than 1.96 so it can be concluded that the competency variable has a significant effect on employee performance variables $\left(\mathrm{H}_{1}\right.$ is accepted).

$\mathrm{H}_{2}$ : Compensation has a significant effect on Employee Performance at Puskesmas in Indragiri Hulu Regency.

The effect of compensation variable on the employee performance variable is 0.253 with a t-statistics value of 2.531 , where the t-statistics value is greater than 1.96 so that it can be concluded that the compensation variable has a significant effect on the employee performance variable $\left(\mathrm{H}_{2}\right.$ is accepted $)$.

\section{$\mathrm{H}_{3}$ : Workshop has a significant effect on Employee Performance at Puskesmas in Indragiri Hulu Regency.}

The effect of workshop variable on the employee performance variable is 0.218 with a t-statistics value of 3.144 , where the tstatistics value is greater than 1.96, so it can be concluded that the workshop variable has a significant effect on employee performance variable $\left(\mathrm{H}_{3}\right.$ is accepted).

$\mathrm{H}_{4}$ : Competence has a significant effect on Employee Performance mediated by Prime Service at Puskesmas in Indragiri Hulu Regency.

The effect of competency variable on employee performance through the prime service variable is 0.090 with a t-statistical value of 2.545, where the t-statistics value is greater than 1.96 so that it can be concluded that the competency variable has a significant effect on employee performance variable mediated by prime service at the Puskesmas in Indragiri Hulu Regency $\left(\mathrm{H}_{4}\right.$ is accepted).

$\mathrm{H}_{5}$ : Compensation has a significant effect on Employee Performance mediated by Prime Service at Puskesmas in Indragiri Hulu Regency.

The effect of compensation variable on employee performance through the prime service variable as mediation is 0.103 with a t-statistics value of 2.437 , where the t-statistics value is greater than 1.96 so that it can be concluded that the compensation variable has a significant effect on employee performance variable mediated by prime service at Puskesmas in Indragiri Hulu Regency $\left(\mathrm{H}_{5}\right.$ is accepted). 
$\mathrm{H}_{6}$ : Workshop has a significant effect on Employee Performance mediated by Prime Service at Puskesmas in Indragiri Hulu Regency.

The effect of workshop variable on employee performance through the prime service variable as mediation is 0.078 with a tstatistical value of 2.541 , where the t-statistics value is greater than 1.96 so that it can be concluded that the workshop variable has a significant effect on employee performance variable mediated by prime service at Puskesmas in Indragiri Hulu Regency ( $\mathrm{H}_{6}$ is accepted).

\section{Discussion}

The results of the hypothesis testing conducted show that competence has a significant effect on employee performance. It means that competence has a significant effect in improving the performance of the Puskesmas employees in Indragiri Hulu Regency. On the other hand, the higher the level of competence, the higher the employee's performance during the work time in the company. This is in line with the research related to competence (Ramo et al., 2009; Chan, 2006; Sengupta et al., 2013; Zainol \& Mamun., 2018; Emmerling et al., 2012; Yang et al., 2012) which concluded that competence has an effect on performance. The results of the hypothesis test conducted show that compensation has a significant effect on employee performance. It means that compensation provides a significant influence in improving the performance of Puskesmas employees in Indragiri Hulu Regency. In other words, the higher the compensation obtained, the higher the employee's performance. It is in line with the previous research related to the worker's compensation (Chong and Law, 2016; Jean et al., 2017; Do, 2018; Feng et al., 2015; Leung and Chan., 2001) who concluded that compensation has an effect on performance of the company workers / employees. The results of the hypothesis testing conducted show that the workshop has a significant effect on employee performance. It means that the workshop has a significant effect in improving the performance of Puskesmas employees in Indragiri Hulu Regency. On the other hand, the more workshop is carried out, the higher the employee's performance. This is in line with research related to the workshop (Ningrum et al., 2013; Elnaga \& Imran, 2013; and Athar and Shah, 2015) who concluded that workshop has an effect on performance. The results of the hypothesis testing conducted show that prime service mediates the influence of competence on the performance of the Puskesmas employees in Indragiri Hulu Regency. This means that prime service has a significant effect in improving employee performance in Indragiri Hulu Regency. Researchers have not found any previous research that discusses the influence of competence on employee performance with prime service as mediation through the analysis of the competence variable on employee performance. The results of the hypothesis testing conducted show that prime service mediates the effect of compensation on the performance of the Puskesmas employees in Indragiri Hulu Regency. This means that prime service has a significant effect in improving employee performance in Indragiri Hulu Regency. Researchers have not found any previous research that discusses the effect of compensation on employee performance with prime service as mediation. The results of the hypothesis testing conducted show that prime service mediates the effect of education and workshop on the performance of Puskesmas employees in Indragiri Hulu Regency. This means that prime service has a significant effect in improving employee performance in Indragiri Hulu Regency. Researchers have not found any previous research that discusses the effect of workshop on employee performance with prime service as mediation.

\section{Conclusions and Implications}

Based on the results of the research and discussion in the previous chapter, the several conclusions can be drawn to answer the research questions as follows.

a. The competency variable has a significant effect on the employee performance at the Puskesmas in Indragiri Hulu Regency. It means that the hypothesis stating competence has a significant effect on employee performance at the Puskesmas in Indragiri Hulu Regency is accepted.

b. The compensation variable has a significant effect on the employee performance at the Puskesmas in Indragiri Hulu Regency. It means that the hypothesis stating that compensation has a significant effect on employee performance at the Puskesmas in Indragiri Hulu Regency is accepted.

c. The workshop variable has a significant effect on the employee performance at the Puskesmas in Indragiri Hulu Regency. It means that the hypothesis which stating that workshop has a significant effect on employee performance at the Puskesmas in Indragiri Hulu Regency is accepted.

d. The prime service variable partially mediates the effect of competence on the employee performance at the Puskesmas in Indragiri Hulu Regency. It means that the hypothesis stating that competence has a significant effect on Employee Performance mediated by Prime Service at the Puskesmas in Indragiri Hulu is accepted.

e. The prime service variable partially mediates the effect of compensation on the employee performance at the Puskesmas in Indragiri Hulu Regency. It means that the hypothesis stating that compensation has a significant effect on Employee Performance mediated by Prime Service at the Puskesmas in Indragiri Hulu is accepted. 
f. The prime service variable partially mediates the effect of workshop on the employee performance at the Puskesmas in Indragiri Hulu Regency. It means that the hypothesis stating that workshop has a significant effect on Employee Performance mediated by Prime Service at the Puskesmas in Indragiri Hulu is accepted.

The implication of the results of this study is to identify that prime service variables can improve employee performance and create a shared perception of the work behavior of public health service employees so that they can provide different support in interactions to provide optimal service according to sustainable Social Exchange Theory.

\section{References}

Adam, F., \& Kamase, J. (2019). The effect competence and motivation to satisfaction and performance. International Journal of Scientific \& Technology Research, 8(3), 132-140.

Ahrul Tsani, F. (2013). Pengaruh Kompetensi, Penempatan Kerja Danmotivasi Terhadap Kinerja Pegawai Sekretariat Jenderal Kementerian Luar Negeri. Jurnal MIX, 3(1).

Anitha, R., \& Kumar, M. A. (2016). A study on the impact of training on employee performance in private insurance sector, Coimbatore district. International Journal of Management Research and Reviews, 6(8), 1079.

Andri, S. (2011). Pengaruh program pendidikan dan latihan terhadap kinerja dan kepuasan kerja karyawan. Jurnal Aplikasi Bisnis, 1(2), 64-77.

Appelbaum, S. H., \& Mackenzie, L. (1996). Compensation in the year 2000: pay for performance?. Health manpower Management.

Astarina, I., Hapsila, A., \& Fitrio, T. (2019). The Influence of Discipline on Lecturers' Motivation and Performance in Indragiri College of Economics (STIE) Rengat. International Journal of Scientific Research and Management, 7(09).

Athar, R., \& Shah, F. M. (2015). Impact of training on employee performance (banking sector Karachi). IOSR Journal of Business and Management, 17(11), 58-67.

Aulia, R., \& Sasmita, J. (2014). Pengaruh pendidikan dan pelatihan kepuasan kerja dan kepemimpinan terhadap kinerja perawat rawat inap di RSUD Kabupaten Siak.

Baledi, M., \& Saed, R. A. (2017). The Impact of Compensation on Improving Employees Performance Through Job Satisfaction in Jordanian Newspaper. International Journal of Business Quantitative Economics and Applied Management Research, 4(5), 86-102.

Baron, R. M., \& Kenny, D. A. (1986). The moderator-mediator variable distinction in social psychological research: Conceptual, strategic, and statistical considerations. Journal of Personality and Social Psychology, $51(6), 1173$.

Barzegar, N., \& Farjad, S. (2011). A study on the impact of on the job training courses on the staff performance (a case study). Procedia-Social and Behavioral Sciences, 29, 1942-1949.

Bento, A., \& White, L. F. (2006). Budgeting, performance evaluation, and compensation: a performance management model.

Chin, W. W., \& Newsted, P. R. (1999). Structural equation modeling analysis with small samples using partial least squares. Statistical Strategies for Small Sample Research, 1(1), 307-341.

Chong, V. K., \& Law, M. B. (2016). The effect of a budget-based incentive compensation scheme on job performance. Journal of Accounting \& Organizational Change, 12(4), 590-613.

Do, T. T. (2018). How spirituality, climate and compensation affect job performance. Social Responsibility Journal, 14(2), 396409.

Elnaga, A., \& Imran, A. (2013). The effect of training on employee performance. European journal of Business and Management, 5(4), 137-147.

Emmerling, R., Boyatzis, R. E., Araujo, S. V. A., \& Taylor, S. N. (2012). The influence of emotional and social competencies on the performance of Peruvian refinery staff. Cross Cultural Management: An International Journal, 19(1), 19-29.

Fahrurrozi, M. (2013). Pengaruh Kualitas Informasi Beras dan Kualitas Pelayanan terhadap Kinerja Perusahaan pada Ud. Barokah Berbah Sleman YOGYAKARTA. Jurnal Manajemen, 3(1), 61-72.

Farooq, M., \& Khan, M. A. (2011). Impact of training and feedback on employee performance. Far East Journal of Psychology and Business, 5(1), 23-33.

Feng, M., \& Saini, J. S. (2015). Monetary compensation, workforce-oriented corporate social responsibility, and firm performance. American Journal of Business, 30(3), 196-215.

Fitrio, T., Budiyanto, B., \& Agustedi, A. (2020). The rule of organizational citizenship behavior and innovative work behavior in mediating the influence of organizational commitment and culture to employee performance. Accounting, 6(7), 13511360 .

Ghozali, I., \& Fuad, M. (2008). Structural equation modeling. Metode Alternatif dengan Partial Least Square. Semarang: Badan Penerbit Universitas Diponegoro.

Hameed, A., Ramzan, M., \& Zubair, H. M. K. (2014). Impact of compensation on employee performance (empirical evidence from banking sector of Pakistan). International Journal of Business and Social Science, 5(2). 
I. Astarina et al. /Accounting 7 (2021)

Ibrahim, R., Boerhannoeddin, A., \& Bakare, K. K. (2017). The effect of soft skills and training methodology on employee performance. European Journal of Training and Development, 41(4), 388-406

Indriani, I. (2018). Pengaruh Kompetensi dan Beban Kerja terhadap Kinerja Pelaksanaan Asuhan Keperawatan pada Bagian Rawat Inap Rumah Sakit Umum Dr Slamet Garut. Jurnal Wacana Ekonomi, 17(2), 025-032.

Jean, K. N., Ngui, T. K., \& Robert, A. (2017). Effect of compensation strategies on employee performance: A Case Study of Mombasa Cement Limited. International Journal of Innovative Social Sciences \& Humanities Research, 5(3), $25-42$.

Khan, N., Ahmad, N., Iqbal, N., \& Haider, N. (2014). Relationship of training and education with employee performance in financial institutions. International Letters of Social and Humanistic Sciences, 41, 150-156.

Komara, A. T., \& Nelliwati, E. (2014). Pengaruh Kompensasi, Motivasi Dan Kepuasan Kerja Terhadap Kinerja Pegawai Negeri Sipil (PNS) Di Lingkungan Rumah Sakit Umum Daerah (RSUD) Kota Bandung. Jurnal Ekonomi, Bisnis \& Entrepreneurship, 8(2), 73-85.

Kum, F. D., Cowden, R., \& Karodia, A. M. (2014). The impact of training and development on employee performance: A case study of ESCON Consulting. Singaporean Journal of Business Economics and Management Studies, 3(3), $72-105$.

Leung, S. T., \& Chan, S. Y. (2001). The Moderating Effects of Personality and Compensation Schemes on the Budgetary Participation-Performance Relationship. Asian Review of Accounting, 9(2), 38-55.

Muqiit, I. M. A., \& Ibrahim, R. (2015). Pengaruh Kompetensi Dan Kepuasan Kerja Terhadap Kinerja Perawat Rumah Sakit Syafira Pekanbaru. Jurnal Online Mahasiswa (JOM) Bidang Ilmu Ekonomi, 1(2), 1-20.

Ningrum, W. (2013). Pengaruh Pendidikan dan Pelatihan Terhadap Kinerja Karyawan (Studi Pada Karyawan Joint Operating Body Pertamina-PertoChina East Java). Jurnal Administrasi Bisnis, 6(2).

Otoo, F. N. K. (2019). Human resource management (HRM) practices and organizational performance. Employee Relations: The International Journal, 41(5), 949-970.

Pakpahan, E. S. (2014). Pengaruh Pendidikan dan Pelatihan terhadap Kinerja Pegawai (Studi pada Badan Kepegawaian Daerah Kota Malang). Jurnal Administrasi Publik, 2(1), 116-121.

Peraturan Gubernur Nomor 33 Tahun (2019) tentang Sisitem Penilaian Prestasi Kerja Pegawai Negeri Sipil secara Elektronik dilingkungan Pemerintah Provinsi Riau. 26 Juli 2019. Berita daerah Provinsi Riau Tahun 2019 Nomor 33.

Peraturan Pemerintah Republik Indonesia Nomor 30 Tahun (2019) tentang Penilaian Kinerja Pegawai. 26 April 2019. Lembar Negara Republik Indonesia Tahun 2019 Nomor 77.

Peraturan Pemerintah Republik Indonesia Nomor 96 tahun 2012 tentang pelaksanaan Undang-Undang Nomor 25 tahun 2009 tentang Pelayanan Publik. 30 Oktober 2012. Lembar Negara Republik Indonesia Tahun 2012 Nomor 215.

Peraturan Pemerintah Republik Indonesia Nomor 53 Tahun 2010 tentang Disiplin Pegawai Negeri Sipil. 6 Juni 2010. Lembar Negara Republik Indonesia Tahun 2010 nomor 74.

Ramadhan, S., Gustopo, D., \& Vitasari, P. (2015). Pengaruh Kompensasi Dan Motivasi Kerja Terhadap Kinerja Karyawan (Studi Pada Perawat Rumah Sakit Islam Dinoyo Malang). Jurnal Teknologi dan Manajemen Industri, 1(2), 36-41.

Ramo, L. G., Saris, W. E., \& Boyatzis, R. E. (2009). The impact of social and emotional competencies on effectiveness of Spanish executives. The Journal of Management Development, 28(9), 771-793.

Ratnasari, S. L. (2016). Pengaruh Kompetensi Dan Kompensasi Terhadap Kinerja Karyawan Departemen Quality Assurance PT. PEB Batam.

Ren, S., Wang, L., Yang, W., \& Wei, F. (2013). The effect of external network competence and intrafirm networks on a firm's innovation performance: The moderating influence of relational governance. Innovation, 15(1), 17-34.

Resurreccion, P. F. (2012). Performance management and compensation as drivers of organization competitiveness: The Philippine perspective. International Journal of Business and Social Science, 3(21).

Rizal, M., Idrus, M. S., \& Djumahir, M. R. (2014). Effect of compensation on motivation, organizational commitment and employee performance (studies at local revenue management in Kendari city). International Journal of Business and Management Invention, 3(2), 64-79.

Santhi, N. H., \& Hartati, W. (2017). Pengaruh Kualitas Pelayanan Terhadap Kinerja dan Kepuasan Mahasiswa (Studi Kasus Pada Mahasiswa STIA Muhammadiyah Selong). Jurnal Humanitas: Katalisator Perubahan dan Inovator Pendidikan, 4(1).

Sengupta, A., Venkatesh, D. N., \& Sinha, A. K. (2013). Developing performance-linked competency model: a tool for competitive advantage. International Journal of Organizational Analysis, 21(4), 504-527.

Shah, M. N., \& Prakash, A. (2018). Developing generic competencies for infrastructure managers in India. International Journal of Managing Projects in Business, 11(2), 366-381.

Singh, K. (2016). Influence of internal service quality on job performance: a case study of Royal Police Department. ProcediaSocial and Behavioral Sciences, 224, 28-34.

Spencer, L. Y. S., \& Spencer, S. (2011). SM (1993). Competence at work. Models for superior performance.

Sukidi, S., \& Wajdi, F. (2017). Pengaruh Motivasi, Kompensasi, dan Kepuasan Kerja Terhadap Kinerja Pegawai Dengan Kepuasan Kerja Sebagai Variabel Intervening. Jurnal Manajemen Dayasaing, 18(2), 79-91.

Tognazzo, A., Gubitta, P., \& Gerli, F. (2017). Fostering performance through leaders' behavioral competencies. International Journal of Organizational Analysis, 25(2), 295-311 
Undang-Undang Nomor 5 Tahun 2014 tentang Aparatur Sipil Negara. 15 Januari 2014. Lembar Negara Republik Indonesia Tahun 2014 Nomor 6.

Undang-Undang Republik Indonesia No. 36 Tahun 2014 tentang Tenaga Kesehatan. 13 Oktober 2009. Lembar Negara Republik Indonesia Tahun 2009 Nomor 144.

Undang-Undang Republik Indonesia No.2 Tahun 1992 tentang usaha perasuransian. 11 Februari 1992. Lembar Negara Republik Indonesia Tahun 1992 Nomor 13.

Vlachos, I. P. (2009). High-performance workplace practices for Greek companies. EuroMed Journal of Business, 4(1), 21-39.

Yang, L. R., Yen, H. F., \& Chiang, Y. F. (2012). A framework for assessing impacts of leadership competency on police project performance. Policing: An International Journal of Police Strategies \& Management, 35(3), 528-550.

Younas, W., Farooq, M., Khalil-Ur-Rehman, F., \& Zreen, A. (2018). The impact of training and development on employee performance. IOSR Journal of Business and Management, IOSR-JBM, 20(7), 20-23.

Yuliana, Y. (2017). Pengaruh Kompetensi Dan Motivasi Kerja Terhadap Kinerja Karyawan Perusahaan Pada Pt Haluan Star Logistic. Ilmiah Manajemen Bisnis.

Zainol, N. R., \& Al Mamun, A. (2018). Entrepreneurial competency, competitive advantage and performance of informal women micro-entrepreneurs in Kelantan, Malaysia. Journal of Enterprising Communities: People and Places in the Global Economy, 12(3), 299-321.

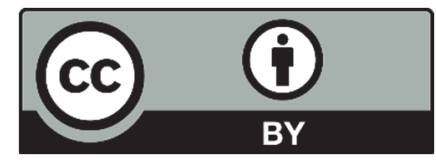

(C) 2021 by the authors; licensee Growing Science, Canada. This is an open access article distributed under the terms and conditions of the Creative Commons Attribution (CC-BY) license (http://creativecommons.org/licenses/by/4.0/). 